\title{
Carbon Emissions from Fuel Combustion in the Economy of the State of Minas Gerais, Brazil (2005-2016)
}

\author{
Marco Paulo Vianna Franco ${ }^{1}$ (D) | Carla Cristina Aguilar de Souza ${ }^{2}$ (D) | Terciane Sabadini \\ Carvalho $^{3}$ iD | Raimundo de Sousa Leal Filho ${ }^{4}$ (D) | Reinaldo Carvalho de Morais ${ }^{5}$ \\ ${ }^{1}$ Diretoria de Estatística e Informações, Fundação João Pinheiro. E-mail: marco.franco@fjp.mg.gov.br \\ ${ }^{2}$ Diretoria de Estatística e Informações, Fundação João Pinheiro. E-mail: carla.aguilar@fjp.mg.gov.br \\ 3 Departamento de Economia, Universidade Federal do Paraná. E-mail: tersabadini@gmail.com \\ ${ }^{4}$ Diretoria de Estatística e Informações, Fundação João Pinheiro. E-mail: raimundo.sousa@fjp.mg.gov.br \\ ${ }^{5}$ Diretoria de Estatística e Informações, Fundação João Pinheiro. E-mail: reinaldo.carvalho@fjp.mg.gov.br
}

\begin{abstract}
The article assesses carbon emissions from fuel combustion in the economy of the Brazilian State of Minas Gerais between 2005 and 2016. An open Leontief model with hybrid units and incorporation of an energy sector was built using available input-output matrices and energy flows by economic sector. Overall, "Transport, storage, and mailing", "Petroleum derivatives and ethanol", and "Metallurgy" remained as the most relevant sectors in terms of emissions. Total and distributive impacts decreased between 2005 and 2013, with a trend reversal between 2013 and 2016. In addition to these sectors, "Mining" and "Agriculture, forestry and logging" were significant sources of emissions embedded in exports. A reduction of approximately $20 \%$ in sectoral average and aggregate emission requirements was observed, despite the substantial growth of the economy of the State in the period. There were decreasing returns to such gains, which, alongside the trend reversal at the end of the period, point to the role of specific macroeconomic factors in the observed outcomes and the need for new initiatives to curb emissions in the future.
\end{abstract}

\section{KEYWORDS}

Input-output analysis, Carbon emissions, Minas Gerais

Emissões de Carbono a partir da Combustão de Combustiveis na Economia do Estado de Minas Gerais, Brasil (2005-2016)

\section{RESUMO}

O trabalho avalia emissões de carbono na economia do Estado de Minas Gerais a partir da queima de combustiveis fósseis (2005-2016). Foi utilizado um modelo insumo-produto aberto de Leontief com unidades híbridas e incorporação de um setor energético com base nas matrizes de insumo-produto estaduais e fluxos energéticos por setor econômico. "Transporte, armazenagem e correio", "Fabricação de derivados do petróleo e álcool" e "Metalurgia" mantiveram-se como os setores mais relevantes no período em termos de emissões.Impactos totais e distributivos decresceram entre 2005 e 2013, com reversão dessa tendência entre 2013 e 2016. Em adição a esses setores, a "Indústria Extrativa Mineral" e a "Agricultura, silvicultura e exploração florestal" se destacaram como fontes de emissões embutidas em exportações. Houve uma redução de aproximadamente $20 \%$ nos requisitos médios por setor e requisitos agregados de emissões, apesar do crescimento substancial da economia mineira no período. Entretanto, tais ganhos apresentaram retornos decrescentes, o que, em conjunto com a reversão da tendência ao final do período, aponta para o papel de fatores macroeconômicos específicos sobre os resultados e para a necessidade de novas iniciativas para a mitigação de emissões no futuro.

PALAVRAS-CHAVE

Análise insumo-produto, Emissões de carbono, Minas Gerais

JEL CLASSIFICATION

C67, E01, Q48 


\section{Introduction}

The anthropogenic character of the elevation of atmospheric concentrations of greenhouse gases, as well as its potentially catastrophic consequences for the maintenance of human and non-human life on a planetary level, are beyond dispute in a scientific context (Rockström et al., 2009). In addition to the extinction of animal and plant species, changing rainfall patterns, rising sea levels, and more frequent severe weather phenomena (e.g. thunderstorms, floods, windstorms, heat waves, and prolonged droughts), the adverse economic effects of climate change include disruptions in water supply, energy generation, and agricultural productivity. The lower technological and financial capacities of developing countries to respond and adapt to such events make them more vulnerable to their effects. In Brazil, in accordance with the Permanent Joint Commission on Climate Change (CMMC), the greatest environmental and socioeconomic damages caused by these occurrences involve:

aggravation of water supply scarcity in the semi-arid Northeast, and loss of biodiversity (including species extinction), replacement of the rainforest by savanna-like vegetation, and desertification and salinization of agricultural land in the Amazon. The loss of areas of rainforest in the Amazon would also entail changes to rainfall patterns in the south-central portion of the country, which is its main agricultural region. Finally, rising sea levels are a threat to Brazilian coastal cities (CMMC, 2013, p. 8, translated by the authors).

Regarding the Brazilian State of Minas Gerais, the State Foundation for the Environment (FEAM) estimates that "since 2008, extreme weather events, such as downbursts and prolonged droughts, cost R $\$ 12.8$ billion. Without proper measures, the cost of the impacts of climate change to the economy of Minas Gerais might reach R $\$ 450$ billion by 2050" (FEAM, 2015, p. 9, translated by the authors). To mitigate these impacts, the State added to its main planning instrument, the Multi-Year Governmental Action Plan 2012-2015 (MINAS GERAIS, 2012), the formulation of sectoral plans for the mitigation and adaptation to climate change and the conception of emission scenarios. In 2015, a political committee was created to oversee the implementation of and revisions to sectoral and transversal actions included in the new Energy and Climate Change Plan of Minas Gerais.

FEAM (2013) presents emissions data by economic sector and subsector of Minas Gerais in 2010. Total emissions amounted to $123,434.3 \mathrm{Gg} \mathrm{CO}_{2} \mathrm{e}$ (Gigagrams or thousand Tons of carbon dioxide equivalent), $0.6 \%$ less than estimates for 2005, implying the stabilization of emissions despite the economic growth observed in the period. ${ }^{1}$ The maintenance of emission levels is mainly due to a significant reduction in deforestation. Emissions arising from land use change decreased by $82 \%$, which means

\footnotetext{
${ }^{1}$ According to the João Pinheiro Foundation (FJP), the economy of Minas Gerais has grown by approximately 25\% between 2005 and 2010 (FJP, 2012).
} 
preventing the emission of $13,742.7 \mathrm{Gg} \mathrm{CO}_{2} \mathrm{e}$ in the period by means of vegetation conservation.

The emission estimates of (FEAM, 2013) were divided into five broad sectors: agriculture and livestock, energy, industrial processes, land use change, and waste treatment. Agriculture and livestock accounted for 39.3\% of total emissions. Livestock was responsible for $60.6 \%$ and agriculture for $39.4 \%$ of sectoral emissions, which stemmed mainly from cattle enteric fermentation, animal waste management, agricultural soil, liming, rice cultivation, and the burning of agricultural waste. Such an expressive representation of the sector can be explained by the relevance of its economic activities, especially cattle and pig husbandry.

The energy sector came in second in terms of emissions, with $36 \%$ of the total. The main associated activities were the burning of fossil fuels and biomass for the production, transformation, and consumption of energy, as well as fugitive emissions from oil and natural gas refining, transport, and distribution. $47.3 \%$ of the emissions of this sector were due to the transport subsector, and $38.6 \%$ to the industrial subsector. If decomposed by fuel type, results indicate that the consumption of diesel oil and gasoline presented the highest shares, with respectively $36.9 \%$ and $13.9 \%$ of sectoral emissions. In the transport subsector, road transportation was accountable for $94.5 \%$ of emissions, of which $67.1 \%$ came from using diesel oil, and $29.4 \%$ from using gasoline.

The sector of industrial processes emitted $15.8 \%$ of the total, which relates to production processes except for burning fuels. The most representative subsector was metallic minerals (53\%), which included the steel and aluminum industries. Nonmetallic minerals also presented significant levels of emissions, especially in connection with the cement industry, with $46.7 \%$ of the total of the sector.

Land use change ${ }^{2}$ and waste treatment entailed lower amounts of emissions, respectively $2.5 \%$ and $6.4 \%$ of the State's total. Emissions (and removals, given the possibility of carbon fixation through forest management) accruing from the former are the result of the final carbon balance after transitions in land use. The emissions of the latter, in turn, originate from waste disposal and treatment, including composting, incineration, and treatment of domestic and industrial effluents.

Nonetheless, the estimates of FEAM (2013) do not consider intersectoral linkages. Studies which disregard the dynamics between economic sectors cannot effectively contribute to the understanding of the ways in which a given productive structure impacts the environment and how these impacts evolve. The supply and demand relations between the agricultural, energy, and industrial sectors, for instance, might

\footnotetext{
${ }^{2}$ The decrease in deforestation rates in Minas Gerais, as well as in other Brazilian States, and mainly in the Amazon region, has been a crucial contribution for the reduction of Brazilian emissions in recent years. Nevertheless, such contributions from the land use change sector are close to their limit, as reductions stop once deforestation is brought to a halt, in addition to the observation that such reductions occur at decreasing rates. Hence, despite the low share of the sector in the total amount of emissions, it is worth noting that keeping low deforestation rates is critical for the success of mitigation policies.
} 
reveal important aspects for the formulation of integrated policies for the mitigation of emissions. According to Carvalho et al. (2013), input-output analysis constitutes an adequate tool for the investigation of environmental impacts due to its observance of the many links between economic sectors.

The production of detailed data and knowledge on the impacts of economic activity over climate change is extremely relevant to the formulation of policies that successfully induce the mitigation of emissions or the adaptation to their effects. Thus, a cautious description of the relations between the productive structure of the State of Minas Gerais and the emissions caused by it, using input-output models, would allow for the proposition of more effective actions. To assess the evolution of such relations in a given time frame may offer a satisfactory appraisal of tendencies and a wider comprehension of the challenges ahead.

This work aimed at the evaluation of the evolution of carbon emissions from fuel combustion in the economy of the State of Minas Gerais between 2005 and 2016. We sought to (i) measure the total emission requirements of 35 sectors in relation to variations in final demand; (ii) identify key sectors of the economy of Minas Gerais in terms of emissions, understood as sectors of special interest for the formulation of mitigation policies; and (iii) analyze the export structure of Minas Gerais pertaining the intensity of emissions embedded in its international trade. For these purposes, an open Leontief input-output model with hybrid units and incorporation of an energy sector was built using input-output matrices available for 2005, 2008, 2013, and 2016, and corresponding energy flows by economic sector. Section 2 discusses the relevant literature; Section 3 describes the methods used; Section 4 deals with data preparation; Section 5 presents and discusses the results; and Section 6 brings some conclusions.

\section{Input-output analysis and carbon emissions}

Input-output analysis, as developed by Leontief (1986), unveils the different manners in which a given economic sector interacts with the rest of the economy. Sectors exert influence over entire productive chains, either directly or indirectly. A meticulous study of intersectoral interlinkages might, therefore, point to characteristics of the whole productive structure which are useful for the formulation of public policies.

Environmental applications of input-output models were devised right after the development of the methodology itself. Leontief himself dealt with environmental impacts and externalities such as air pollution (Leontief, 1986, pp. 241-293). Such applications have grown in number and scope in recent decades, also in response to the deterioration of environmental problems on a planetary level and as a consequence of the need for more information and knowledge which might support new policies for an ecologically sustainable development (Hawdon and Pearson, 1995).

Among the environmental applications of input-output models, there are those 
focused on the analysis of energy flows in an economic context. ${ }^{3}$ These initiatives tackle the issues of sectoral policies for energy provisioning and efficiency, demand and technological changes, and broader relations between economic development and energy consumption (Alcántara and Padilla, 2003; Gowdy and Miller, 1987; Perobelli et al., 2007).

A more specific trend within studies on energy flows of economic interest aims at anthropogenic carbon emissions and their effects over the climate. The direct relationship between the use of fossil fuels and energy flows through economic sectors ${ }^{4}$ suggests that input-output models could be an appropriate way to enhance our understanding of how emissions are distributed and interlinked in a given economy and which sectors would be more sensitive or responsive to mitigation policies. International examples of such studies include Proops et al. (1993), Gay and Proops (1993), Hetherington (1996), Lenzen (1998), Labandeira and Labeaga (2002), and Tarancón and González (2007). In the context of the Brazilian economy, more recent works are Machado (2002), Hilgemberg (2004), Hilgemberg and Guilhoto (2006), Perobelli et al. (2007), Carvalho and Perobelli (2009), Carvalho et al. (2013), Perobelli et al. (2015), and Vale et al. (2018).

Perobelli et al. (2007) analyzed the energy interactions between the State of Minas Gerais and the rest of Brazil, using an inter-regional input-output model with 13 sectors and the incorporation of an energy sector. In this model, sales of the energy sector to other sectors were computed in physical units of energy (Toe, Tons of oil equivalent) instead of in monetary units, which means the adoption of a "hybrid" matrix with elements in both energy and monetary units. Using data on energy consumption in Minas Gerais in 2003 and an input-output matrix for 1996, the authors ascertained that "economic sectors within Minas Gerais are a greater source of pressure over the energy sector of the State than the same sectors from the rest of the country" (p. 127, translated by the authors). They identified the sectors "Iron and Steel", "Transport", "Energy", and "Other industries" as the main sources of pressure from within Minas Gerais over the demand of the energy sector; the sectors "Energy", "Transport", "Other industries", and "Food and beverage" were pinpointed as important sources from outside the State.

Carvalho et al. (2013) computed the intensity of emissions in Minas Gerais in 2005 by means of a hybrid regional input-output model with 35 sectors. They identified as key sectors ${ }^{5}$ in terms of emissions "Agriculture, forestry and logging", "Livestock production and fishing”, "Mining”, "Food products”, “Cellulose and paper”, "Petroleum derivatives and ethanol”, "Chemical products”, “Non-metallic minerals products”, "Met-

\footnotetext{
${ }^{3} \mathrm{~A}$ brief history of energy applications of input-output models can be found in Hannon (2010).

${ }^{4}$ According to Steffen et al. (2007), ca. 80\% of all the energy consumed by the global economy in 2000 originated in energy systems based on fossil fuels.

${ }^{5}$ The concept of key sector was devised by Rasmussen (1956) based on the multiplying effects of final demand. To Souza et al. (2017, p. 104, translated by the authors), "sectors with the highest positive effects over the productive structure are known as key sectors and, given such a multiplying character, constitute valuable information for the conception of economic policies".
} 
allurgy", "Automotive vehicles", "Construction", and "Transport, storage and mailing". The sectors "Petroleum derivatives and ethanol", "Non-metallic minerals products" and "Mining" led to the highest amounts of emissions associated with exports by monetary unit sales. The authors attributed the high intensity of emissions embedded in the exports of the State ${ }^{6}$ to the pollution haven hypothesis: countries with looser environmental regulation would be more competitive in the production of pollutionintensive goods, exporting such goods to countries with more restrictive environmental legislation (Mongelli et al., 2006).

The present work also used a hybrid input-output model with the incorporation of an energy sector, energy consumption data, and matrices for Minas Gerais in 2005, 2008, 2013, and 2016, the only years for which such matrices are available. Our focus was the observation of the evolution of the productive structure of the State in this period, and especially how each sector behaved in terms of emissions and how intensive were emissions embedded in international exports. The answers to these questions proved to be useful for drawing conclusions on how sectoral emissions varied in this economy over time.

\section{Method}

The methodology adopted here takes after the concept of generalized input-output analysis given by Miller and Blair (2009), in which rows and columns are added to a matrix of technical coefficients in order to incorporate a determined phenomenon, in this case carbon emissions. The matrix representation of such a system is

$$
A X+Y=X
$$

with $A$ as the matrix of direct coefficients, indicating the quantity of input from sector $i$ that is necessary to yield a unit of final output in sector $j$; $X$ is the vector of total production values by sector $i$; and $Y$ is the final demand by sector $i$. The total production needed to cover the final demand is, thus, given by:

$$
X=L Y,
$$

with $L=(I-A)^{-1}$ as the matrix of direct and indirect coefficients, also known as the Leontief inverse matrix. The elements of this matrix are interpreted as the total production of sector $i$ that is necessary to yield a unit of final demand in sector $j$.

\subsection{Hybrid-unit input-output matrices}

The construction of hybrid-unit input-output matrices aims at the incorporation of physical flows in the economic analysis, given in physical units, maintaining, however, the monetary flows that are typical of input-output models. Thus, in accordance with

\footnotetext{
${ }^{6}$ Carvalho and Perobelli (2009) reached the same conclusion for Brazilian exports.
} 
Miller and Blair (2009) and bearing in mind our objective, it is possible and appropriate to build matrices of emission flows ${ }^{7}, Z^{e}$, of direct emission requirements, $A^{e}$, and of total emission requirements, $L^{e} \cdot 8$

Emission flows are computed according to the identity

$$
E u+q=g,
$$

in which $E u$ is given by the multiplication of the line vector of emission flows from the energy sector to the rest of the economy, $E$, by the unit vector $i$; $q$ represents the final demand for emissions and $g$ the total demand for emissions. Thus, matrix $Z^{e}$ will be constituted by the lines of the intersectoral monetary flows matrix $Z$, except for the line corresponding to the energy sector, which is to be replaced by the line vector $E$, given in physical units (Gg):

$$
Z^{e}=\left[\begin{array}{cccc}
\$ & \$ & \cdots & \$ \\
G g & G g & \cdots & G g \\
\$ & \$ & \cdots & \$ \\
\vdots & \vdots & \ddots & \vdots \\
\$ & \$ & \cdots & \$
\end{array}\right]
$$

Analogously, the matrices of final demand, $F^{e}$, and of production, $X^{e}$, will be hybrid:

$$
F^{e}=\left[\begin{array}{c}
\$ \\
G g \\
\$ \\
\vdots \\
\$
\end{array}\right] ; X^{e}=\left[\begin{array}{c}
\$ \\
G g \\
\$ \\
\vdots \\
\$
\end{array}\right]
$$

If we define $Z=A(\operatorname{diag}(X))$, equaling the matrix of intersectoral flows with the multiplication of the matrix of technical coefficients by the diagonal matrix of sectoral production, then the matrix of direct emission requirements, $A^{e}$, will be given by

$$
A^{e}=Z^{e}\left[\operatorname{diag}\left(X^{e}\right)\right]^{-1}
$$

As in the original input-output model, the Leontief inverse matrix, henceforth called the total emission requirements matrix, $L^{e}$, is given by ${ }^{9}$

$$
L^{e}=\left(I-A^{e}\right)^{-1} .
$$

\footnotetext{
${ }^{7}$ Emissions are seen as embedded in purchases and sales of fuel, which translate into flows of energy or emissions, interchangeably related through a conversion factor (Table 1).

${ }^{8}$ The regional character of the input-output model adopted here constitutes a methodological limitation in the sense that it does not take into account inter-regional economic dynamics in terms of flows between Minas Gerais and other regions. Yet, possible interferences caused by such a limitation tends to be less relevant in the context of emissions, since it is unlikely that the most intensive sectors (presented in Section 5) have gone through considerable structural changes in the period.

${ }^{9} \mathrm{I}$ is the identity matrix.
} 
The application of energy conservation laws to economic sectors implies that energy and, thus, emissions - embedded in the product of a sector $i$ is equal to the sum of the energy embedded in all inputs of that sector and primary energy inputs originating from the energy sector as fuels (apart from energy losses). Represented as matrices, we have

$$
\alpha\left(\operatorname{diag}\left(X^{e}\right)\right)=\alpha Z^{e}+G^{e}
$$

with total emission requirements given by line vector $\alpha$ and primary energy inputs by $G^{e}$. Using the relation $Z=A(\operatorname{diag}(X))$ and rearranging the terms, (6) becomes

$$
\alpha=G^{e}\left(\operatorname{inv}\left(\operatorname{diag}\left(X^{e}\right)\right)\right)\left(I-A^{e}\right)^{-1} .
$$

Finally, direct and indirect emission requirements are, respectively:

$$
\begin{gathered}
\delta=G^{e}\left(\operatorname{inv}\left(\operatorname{diag}\left(X^{e}\right)\right)\right)\left(I-A^{e}\right) \\
\gamma=\alpha-\delta
\end{gathered}
$$

\subsection{Sectoral impacts and key sectors in terms of emissions}

Sectoral impacts analysis and the identification of key sectors in terms of emissions is based on similar methods used in assessments such as Alcántara and Padilla (2003), Carvalho and Perobelli (2009), and Carvalho et al. (2013). The goal is to build a matrix of intersectoral demand elasticities in relation to final energy consumption (which yields a proportional "emission consumption"). If $\Gamma$ is the total energy use in the productive structure and $\tau$ is the line vector corresponding to energy use by unit of sectoral product, we have:

$$
\Gamma=\tau X^{e}=\tau L^{e} F^{e}
$$

Hence, a variation in energy use, $\Gamma$, is associated with a proportional variation in final demand, $\gamma$ :

$$
\Delta \Gamma=\tau \Delta X^{e}=\tau L^{e} \Delta F^{e}=\tau L^{e} F^{e} \gamma
$$

Be $s$ a vector of the share of sectoral final demands in the production of their respective sectors. Then

$$
F^{e}=\operatorname{diag}\left(X^{e}\right) * s
$$

If we substitute (12) in (11) and divide the resulting equation by $\Gamma$, we reach an expression for the elasticity of the total energy use in the productive structure in relation to 
final demand:

$$
\Gamma^{-1} \Delta \Gamma=\Gamma^{-1} \tau L^{e} \operatorname{diag}\left(X^{e}\right) s \gamma
$$

Moreover, in order to disaggregate this elasticity by sector, we need to express the line vector of sectoral consumption coefficients, $\tau$, in terms of the final energy distribution among all sectors, given by the line vector $d$, with $\sum_{i=1}^{n} d_{i}=1$ :

$$
\tau=\Gamma d\left[\operatorname{diag}\left(X^{e}\right)\right]^{-1}
$$

Replacing $\tau$ according to (14) in (13) yields

$$
\Gamma^{-1} * \Delta \Gamma=d\left[\operatorname{diag}\left(X^{e}\right)\right]^{-1} L^{e} \operatorname{diag}\left(X^{e}\right) s \gamma
$$

If we diagonalize vector $s$ and line vector $d$ and omit $\gamma$ (i.e., considering the standard case of a $1 \%$ variation in final demand), we obtain the following relation for the elasticity matrix $\Gamma^{\varepsilon}$, which gives the proportional variation of energy consumption by sector in relation to a unit change in final demand:

$$
\Gamma^{\varepsilon}=\operatorname{diag}(d)\left[\operatorname{diag}\left(X^{e}\right)\right]^{-1} L^{e} \operatorname{diag}\left(X^{e}\right) \operatorname{diag}(s)
$$

The elements of matrix $\Gamma^{\varepsilon}, \tau_{i} j^{\varepsilon}$, express the percentage variation in the final energy consumption of sector $i$ in response to a variation of $1 \%$ in the final demand of sector $j$. The sum of the elements in column $j$ represents the percentage variation in the total energy consumption in the whole economy in response to a variation of $1 \%$ in the final demand of sector $j$. The sum of the elements in line $i$ represents the percentage variation in the final energy consumption of sector $i$ in response to a variation of $1 \%$ in the final demand of the economy. These sums were dubbed respectively as the "total impact" and "distributive impact" of a given sector (Alcántara and Padilla, 2003). A high total impact means a high energy content of sectoral purchases; a high distributive impact means that sectoral energy consumption is strongly driven by the demand of other sectors.

Key sectors are those whose total and distributive impacts are greater than the median values of total $\left(\Gamma_{T}^{\varepsilon}\right)$ and distributive $\left(\Gamma_{D}^{\varepsilon}\right)$ impacts. If, for a given sector, $\sum_{i} \tau_{i} j^{\varepsilon}<$ $\Gamma_{T}^{\varepsilon}$ and $\sum_{j} \tau_{i} j^{\varepsilon}>\Gamma_{D}^{\varepsilon}$, then its relevance in terms of emissions is connected with the demand of other sectors. If $\sum_{i} \tau_{i} j^{\varepsilon}>\Gamma_{T}^{\varepsilon}$ and $\sum_{j} \tau_{i} j^{\varepsilon}<\Gamma_{D}^{\varepsilon}$, its relevance stems from its own demand. If $\sum_{i} \tau_{i} j^{\varepsilon}<\Gamma_{T}^{\varepsilon}$ and $\sum_{j} \tau_{i} j^{\varepsilon}<\Gamma_{D}^{\varepsilon}$, it is not a relevant sector for the analysis of emissions.

\subsection{Emissions embedded in exports}

Emissions embedded in international exports can be obtained from the correspondence between the vector of emissions from the energy sector and the product between total emission requirements and final demand, which ensures the consistency of the 
model for a closed economy (Machado, 2002):

$$
G^{e}=\alpha F^{e}
$$

Since exports $(\Theta)$ constitute part of the final demand, (17) can be adapted to consider only the emissions embedded in exports by sector, $K^{e}$ :

$$
K^{e}=\alpha \Theta
$$

\section{Data preparation}

The necessary data consisted mainly in the input-output matrices for Minas Gerais in 2005, 2008, 2013, and 2016, provided by FJP (2008, 2015, 2018b, 2020), and energy data for these same years, available from CEMIG (2000). ${ }^{10}$

The preparation of the data involved efforts to make compatible the different sector compositions between the matrices and between them and the energy data. The chosen sector composition was that of the 2005 matrix, given its lower level of disaggregation. Thus, a hybrid input-output matrix with 35 sectors was built for the four years in question (the higher disaggregation of the 2008, 2013, and 2016 matrices called for compatibility techniques based on sectoral production values). With the matrices of intersectoral monetary flows at hand, their hybridization consisted in replacing monetary values in the line of the energy sector ("Petroleum derivatives and ethanol”) by values in physical units (Gg). The same process was performed to the vectors of production and final demand. Besides, to compensate for the loss of monetary values and, thus, keep the balance of the matrices of intersectoral flows in terms of supply and demand, they were adjusted by a factor equal to the ratio between the total sum of intermediate goods and this same sum subtracted from the line of the energy sector. Again, the same process was performed to the vectors of production and final demand.

It should be noted that such sectoral composition compatibilization procedures hinder the possibility to properly account for inflation between periods. The calculation of emissions per unit of GDP, for example, would ideally go through a deflation process, so that the effect of price changes over variables of interest is removed. However, according to Miller and Blair (2009), matrix deflation calls for sectoral price indices, which, in this case, is prevented due to the existence of different matrix sizes and sectoral compositions (as well as the diverse methodologies used for the construction of price indices). In an attempt to approximately account for inflation effects, it has been decided to uniformly deflate the matrices according to the Extended National Consumer Price Index (IPCA - Índice Nacional de Preços ao Consumidor Amplo). Thus, monetary results are presented in 2005 values, with coefficients equal to 0.873 ,

\footnotetext{
${ }^{10}$ CEMIG (Companhia Energética de Minas Gerais) is the biggest electric utility of Minas Gerais and sponsors yearly surveys on the energy balance of the economy of the State.
} 
0.662, and 0.529 being applied respectively for 2008, 2013, and 2016.

The disaggregation of the energy data from 12 into 35 sectors was done in accordance with the premise that emissions are directly proportional to production. Furthermore, the correspondence between the 35 sectors of the matrices and the 12 sectors of the energy data were the same as those adopted by Carvalho et al. (2013).

Elements in physical units had to go through the conversion from energy (Toe) to emission (Gg) units. The conversion factors were taken from Alvim (2000) (Table 1). It is worth noting that this study considered only emissions accruing from the combustion of fossil fuels or biomass, which included diesel oil, biodiesel, fuel oil, gasoline, liquefied petroleum gas (LPG), kerosene, coke gas, coke, ethanol, and other secondary sources.

\section{Results and discussion}

The results are divided into three main parts: total emission requirements, key sectors in terms of emissions, and emissions embedded in exports. The evolution observed from 2005 to 2016 is emphasized as a novel element in the literature and as an attempt to elucidate tendencies and circumstances related to the emissions of the productive structure of the State.

Before delving into the results, a few remarks are applicable. Firstly, the total emissions from fuel combustion computed by the model $\left(G^{e}\right)$ remained practically constant during the observed period (a small increase of $0.4 \%$, from $77,362.78 \mathrm{Gg} \mathrm{CO}_{2} \mathrm{e}$ in 2005 to $77,689.38 \mathrm{Gg} \mathrm{CO}_{2} \mathrm{e}$ in 2016). It is also worth noticing that, between 2013 and 2016, total emissions dropped by $6.1 \%$.

Secondly, the results obtained by Carvalho et al. (2013) for 2005 were not exactly the same as those presented here. Of a total of 35 sectors, only 16 had their classifications match for total and distributive impacts. Such divergences may be attributed to methodological differences, the most evident one being the wider range of fuel sources considered here. ${ }^{11}$ The adoption of different techniques and premises related to data aggregation and preparation might also have played a role in this regard. Finally, it must be mentioned that the methodology used by FJP (2008) to elaborate the 2005 matrix did not consider sectoral secondary production, as was the case for the 2008 , 2013, and 2016 matrices, what might also lead to some distortion in the results. Having established such methodological divergences or limitations, we move on to the results themselves.

\footnotetext{
${ }^{11}$ Carvalho et al. (2013) considered emissions from diesel oil, fuel oil, gasoline, LPG, kerosene, and other petroleum derivatives.
} 
Table 1. Emissions conversion factors (Gg/Toe)

\begin{tabular}{|c|c|c|c|c|c|c|c|c|c|c|}
\hline \multirow{2}{*}{$\begin{array}{l}\text { Sector } \\
\text { Agriculture/Livestock }\end{array}$} & \multirow{2}{*}{$\begin{array}{l}\text { Diesel } \\
\text { Oil } \\
3.07\end{array}$} & \multirow{2}{*}{$\begin{array}{l}\text { Biodiesel } \\
3.07\end{array}$} & \multirow{2}{*}{$\begin{array}{l}{ }_{1}^{\text {Fuel }} \\
3.21\end{array}$} & \multicolumn{2}{|c|}{ Gasoline LPG } & \multirow{2}{*}{$\begin{array}{l}\text { Kerosen } \\
2.98\end{array}$} & \multirow{2}{*}{$\begin{array}{c}{ }_{\text {Gas }}^{\text {Coke }} \\
3.07\end{array}$} & \multirow{2}{*}{$\begin{array}{l}\text { Coke } \\
3.78\end{array}$} & \multirow{2}{*}{$\begin{array}{l}\text { Ethanol } \\
2.39\end{array}$} & \multirow{2}{*}{$\begin{array}{l}\begin{array}{l}\text { Other } \\
\text { Sec- } \\
\text { ondary } \\
\text { Sources }\end{array} \\
3.07\end{array}$} \\
\hline & & & & 2.87 & 2.61 & & & & & \\
\hline Mining & 3.07 & 3.07 & 3.21 & 2.87 & 2.62 & 2.98 & 3.07 & 3.93 & 2.8 & 3.07 \\
\hline Non-metallic Minerals & 3.07 & 3.07 & 3.21 & 2.87 & 2.62 & 2.98 & 3.07 & 3.93 & 2.8 & 3.07 \\
\hline Metallurgy & 3.07 & 3.07 & 3.21 & 2.87 & 2.62 & 2.98 & 3.07 & 3.93 & 2.8 & 3.07 \\
\hline Cellulose and paper & 3.07 & 3.07 & 3.21 & 2.87 & 2.62 & 2.98 & 3.07 & 3.93 & 2.8 & 3.07 \\
\hline Chemical products & 3.07 & 3.07 & 3.21 & 2.87 & 2.62 & 2.98 & 3.07 & 3.93 & 2.8 & 3.07 \\
\hline Food and beverage & 3.07 & 3.07 & 3.21 & 2.87 & 2.61 & 2.98 & 3.07 & 3.81 & 3.03 & 3.07 \\
\hline Textiles & 3.07 & 3.07 & 3.21 & 2.87 & 2.62 & 2.98 & 3.07 & 3.93 & 2.8 & 3.07 \\
\hline Other industries & 3.07 & 3.07 & 3.21 & 2.87 & 2.62 & 2.98 & 3.07 & 3.93 & 2.8 & 3.07 \\
\hline Trade and Services & 3.07 & 3.07 & 3.21 & 2.87 & 2.61 & 2.98 & 3.07 & 3.81 & 2.71 & 3.07 \\
\hline Transport & 3 & 3.07 & 3.21 & 2.35 & 2.62 & 2.97 & 3.07 & 3.95 & 2.76 & 3.07 \\
\hline Public Services & 3.07 & 3.07 & 3.21 & 2.87 & 2.62 & 2.98 & 3.07 & 3.93 & 2.8 & 3.07 \\
\hline Energy Sector & 3.07 & 3.07 & 3.21 & 2.87 & 2.61 & 2.98 & 3.07 & 3.94 & 3 & 3.07 \\
\hline
\end{tabular}

Source: The authors, adapted from Alvim (2000).

\subsection{Total emission requirements}

Table 2 brings the total emission requirements for the 35 sectors in each of the four years. As a general rule, there was a reduction of total requirements over the period caused mainly by comparatively steeper decreases between 2005 and 2008. Conversely, the highest number of sectors (eleven) in which total requirements increased was observed between 2013 and 2016. The sectors which experienced overall gains in total requirements were "Electricity, gas, water and urban sanitation", "Finance and insurance", "Other services", "Metallurgy" and "Metallic products (except machinery and equipment)". Shortages in water availability around 2013 and the ensuing surge in thermoelectric energy consumption might explain these results for the first sector, while the two service sectors might have been influenced by their interlinkages with fuel-intensive sectors. The main mechanism underlying changes in the iron-based industrial sectors was the volatility of commodity prices, which clearly was not sufficiently accounted for by the deflation process. Although these results reveal a certain 
Table 2. Total emission requirements by sector

\begin{tabular}{|c|c|c|c|c|c|c|c|c|c|}
\hline Sector & 2005 & 2008 & 2013 & 2016 & Sector & 2005 & 2008 & 2013 & 2016 \\
\hline $\begin{array}{l}\text { Agriculture, } \\
\text { forestry and logging }\end{array}$ & 0.1634 & 0.1304 & 0.1449 & 0.1414 & $\begin{array}{l}\text { Electrical materials, } \\
\text { appliances and } \\
\text { equipment }\end{array}$ & 0.2154 & 0.1033 & 0.0777 & 0.0760 \\
\hline $\begin{array}{l}\text { Livestock produc- } \\
\text { tion and fishing }\end{array}$ & 0.1718 & 0.1392 & 0.1588 & 0.1618 & Automotive vehicles & 0.2247 & 0.1063 & 0.1083 & 0.0967 \\
\hline Mining & 0.2550 & 0.1700 & 0.0897 & 0.1237 & $\begin{array}{l}\text { Parts and acces- } \\
\text { sories for vehicles }\end{array}$ & 0.2809 & 0.1095 & 0.1147 & 0.1132 \\
\hline Food products & 0.1702 & 0.1390 & 0.1366 & 0.1363 & $\begin{array}{l}\text { Other transport } \\
\text { equipment }\end{array}$ & 0.2254 & 0.1064 & 0.0883 & 0.0618 \\
\hline Beverage products & 0.1651 & 0.1390 & 0.1161 & 0.1094 & $\begin{array}{l}\text { Furniture, wood } \\
\text { products and sun- } \\
\text { dries }\end{array}$ & 0.1319 & 0.0892 & 0.0589 & 0.0580 \\
\hline Tobacco products & 0.1358 & 0.0287 & 0.0620 & 0.0931 & $\begin{array}{l}\text { Electricity, gas, wa- } \\
\text { ter, and urban sani- } \\
\text { tation }\end{array}$ & 0.0262 & 0.0230 & 0.0359 & 0.0424 \\
\hline Textile products & 0.1519 & 0.1229 & 0.1323 & 0.1295 & Construction & 0.1857 & 0.1262 & 0.0952 & 0.0799 \\
\hline $\begin{array}{l}\text { Leather goods and } \\
\text { footwear }\end{array}$ & 0.1753 & 0.1454 & 0.1306 & 0.1357 & Trade & 0.0686 & 0.0454 & 0.0521 & 0.0559 \\
\hline $\begin{array}{l}\text { Clothing and acces- } \\
\text { sories }\end{array}$ & 0.1389 & 0.1270 & 0.1076 & 0.1071 & $\begin{array}{l}\text { Transport, storage } \\
\text { and mailing }\end{array}$ & 1.8660 & 1.6247 & 1.6342 & 1.8087 \\
\hline Cellulose and paper & 0.1680 & 0.0974 & 0.1031 & 0.1009 & $\begin{array}{l}\text { Information ser- } \\
\text { vices }\end{array}$ & 0.0494 & 0.0523 & 0.0249 & 0.0282 \\
\hline $\begin{array}{l}\text { Petroleum deriva- } \\
\text { tives and ethanol }\end{array}$ & 1.7399 & 1.7132 & 1.6302 & 1.6683 & $\begin{array}{l}\text { Finance and insur- } \\
\text { ance }\end{array}$ & 0.0294 & 0.0277 & 0.0389 & 0.0336 \\
\hline $\begin{array}{l}\text { Pharmaceuticals, } \\
\text { perfumery, hygiene } \\
\text { and cleaning }\end{array}$ & 0.1932 & 0.1482 & 0.1091 & 0.1041 & $\begin{array}{l}\text { Real state and } \\
\text { rental }\end{array}$ & 0.0123 & 0.0084 & 0.0072 & 0.0062 \\
\hline Rubber and plastic & 0.1970 & 0.0850 & 0.0838 & 0.0809 & $\begin{array}{l}\text { Accommodation } \\
\text { and food services }\end{array}$ & 0.0492 & 0.0468 & 0.0389 & 0.0439 \\
\hline Chemical products & 0.1702 & 0.1413 & 0.1254 & 0.1176 & Business services & 0.0368 & 0.0276 & 0.0240 & 0.0230 \\
\hline $\begin{array}{l}\text { Non-metallic miner- } \\
\text { als products }\end{array}$ & 0.8090 & 0.8152 & 0.7924 & 0.7052 & $\begin{array}{l}\text { Education and } \\
\text { health markets }\end{array}$ & 0.0595 & 0.0428 & 0.0281 & 0.0287 \\
\hline Metallurgy & 0.8227 & 0.5887 & 0.6945 & 0.8429 & $\begin{array}{l}\text { Public administra- } \\
\text { tion }\end{array}$ & 0.0245 & 0.0198 & 0.0178 & 0.0162 \\
\hline $\begin{array}{l}\text { Metallic products } \\
\text { (except machinery } \\
\text { and equipment) }\end{array}$ & 0.8398 & 0.5758 & 0.6660 & 0.8405 & Other services & 0.0532 & 0.0283 & 0.0222 & 0.0704 \\
\hline $\begin{array}{l}\text { Machinery and } \\
\text { equipment }\end{array}$ & 0.2992 & 0.0872 & 0.0711 & 0.0729 & & & & & \\
\hline
\end{tabular}

Source: The authors. 
and non-monotonous tendency toward lower intensities in the use of fuel combustion in the productive structure of the State, they are still far from offsetting its economic growth in the entire period. ${ }^{12}$ Moreover, the fact that reductions concentrated in the earliest years of the period (2005-2008) and increased in the last ones (2013-2016) corroborates the assumption that these variations were more likely the consequence of specific economic circumstances than a gradual change of productive technologies toward a less intensive economy in terms of emissions.

In 2005, the sector "Transport, storage and mailing" presented the highest total emission requirements, dumping 1,866 Tons of carbon in the atmosphere for every $\mathrm{R} \$ 1,000,000$ of final demand, with "Petroleum derivatives and ethanol" in a close second place. "Non-metallic minerals products", "Metallurgy", and "Metallic products (except machinery and equipment)" are also sectors with high total emission requirements, all of them producing around 800 Tons of carbon emissions for every $\mathrm{R} \$ 1.000 .000$ of final demand. The other sectors did not present relevant total emission requirements in comparison with the above.

In 2016, the two leading sectors held their positions. Total requirements for "Transport, storage and mailing" fell by approximately $3.1 \%$, despite the $10.7 \%$ increase between 2013 and 2016; for "Petroleum derivatives and ethanol", total requirements fell by $4.1 \%$ and increased by $2.3 \%$ in the last four years of the period, which could be attributed to price-based substitution between different types of fuels. "Non-metallic minerals products" had its total requirements reduced by $2.8 \%$, half of it between 2013 and 2016. On the other hand, "Metallurgy" and "Metallic products (except machinery and equipment)" had their emissions per $\mathrm{R} \$ 1.000 .000$ of final demand sharply increased by more than $20 \%$ over the last four years, pointing to an unusual conjuncture for the iron-based industries, as mentioned above, namely the drastic reduction of iron ore prices in international markets.

Figure 1 presents the sectoral averages of total emission requirements for each year, as well as the total requirement for the economy of Minas Gerais, which was calculated by means of the sum of sectoral requirements weighed by their share in the aggregate of the economy of the State. There was a reduction in sectoral averages of total emission requirements of $19.3 \%$ and one of $22.0 \%$ in terms of the aggregate of the economy. However, there were decreasing returns to reductions and a trend reversal between 2013 and 2016, revealing either the cited dependence on the economic conjuncture (effective demand, supply, prices etc.) or the possibility of saturation of the causal forces at play, such as efficiency gains and substitution between fuel types. Results for more recent years will be crucial for the understanding of such a trend and its causes, despite the influence of economic crises of an exogenous character (political turmoil, natural disasters, epidemics, etc.) which have lately been lingering in Brazil.

\footnotetext{
${ }^{12}$ The economy of Minas Gerais has grown approximately three times over in volume between 2005 and 2016 (FJP, 2018a).
} 
Figure 1. Total emission requirements (in $\mathrm{Gg}$ ): sectoral averages and aggregate for the economy of Minas Gerais in 2005, 2008, 2013, and 2016

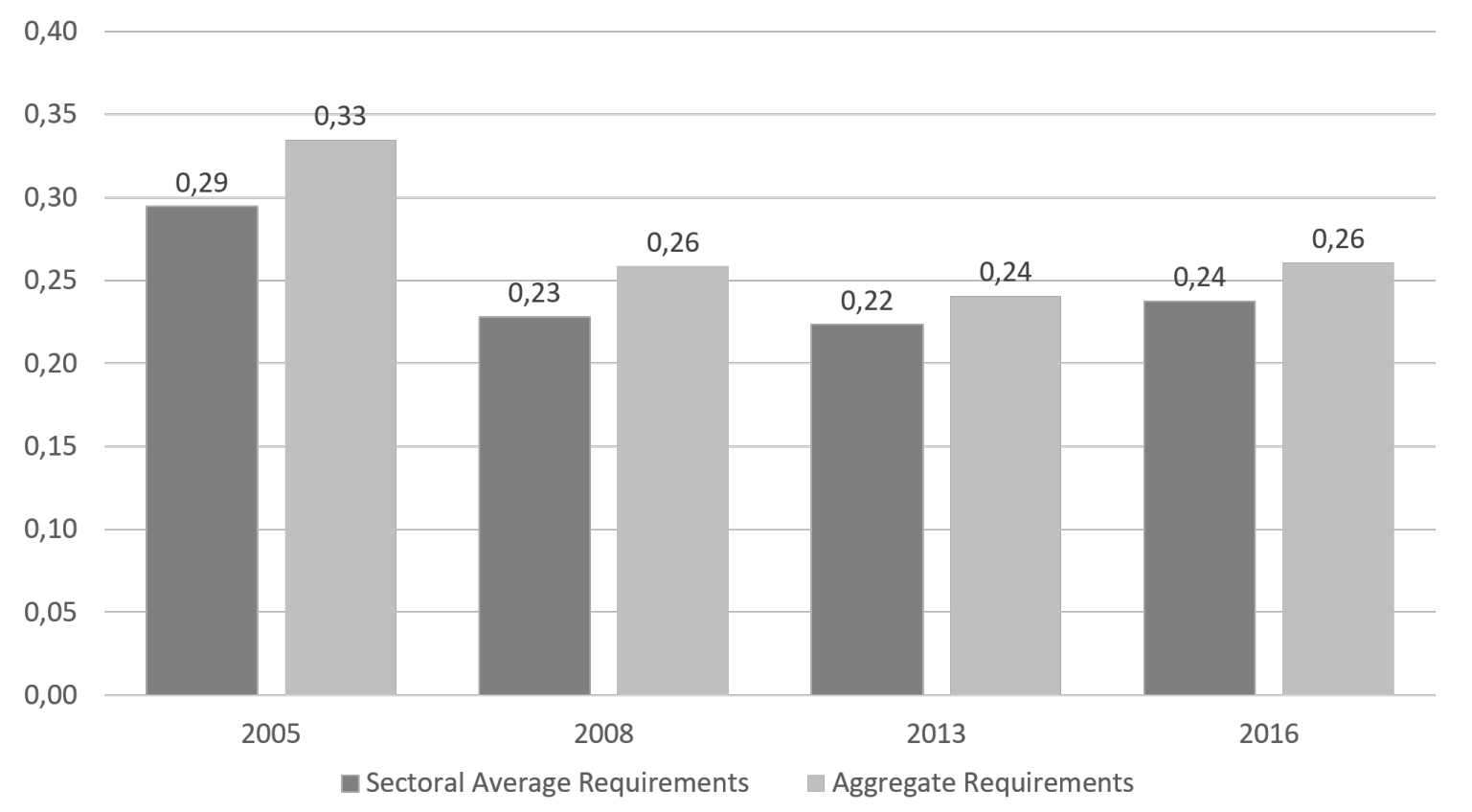

Source: The authors.

\subsection{Key sectors in terms of emissions}

The classification of each of the 35 sectors is presented in Table 3. According to the definitions provided in Section 3.2, sectors were divided into those with total and distributive impacts higher than median values (KEY), those with only total impacts higher than median values (TOT), those with only distributive impacts higher than median values (DIS) and those with both total and distributive impacts lower than median values (-).

Results point to a certain stability in the period, with key sectors concentrated in activities related to agriculture, livestock, mining, manufacturing, and transports. There were 11 key sectors in 2005, 15 in 2008 and 2013, and only 07 in 2016. Thus, it could be said that a considerable amount of emissions is tied to a relatively high number of sectors presenting strong productive interlinkages. Mitigation policies focused on these sectors would lead to meaningful economic impacts for the State. Conversely, the reduction in the number of key sectors in 2016, which is associated to changes in intersectoral linkages, might point toward sector-specific policies with high effectivity (e.g. policies focused on activities related to agriculture, food products, mining, metals, and transport). It is also worth mentioning that several key sectors in 2013 (e.g. "Mining", "Textile products", "Leather goods and footwear", "Clothing and accessories", and "Pharmaceuticals, perfumery, hygiene and cleaning") became 
Table 3. Key sectors in terms of emissions

\begin{tabular}{|c|c|c|c|c|c|c|c|c|c|}
\hline Sector & 2005 & 2008 & 2013 & 2016 & Sector & 2005 & 2008 & 2013 & 2016 \\
\hline $\begin{array}{l}\text { Agriculture, } \\
\text { forestry and logging }\end{array}$ & DIS & KEY & KEY & KEY & $\begin{array}{l}\text { Electrical materials, } \\
\text { appliances and } \\
\text { equipment }\end{array}$ & TOT & TOT & - & - \\
\hline $\begin{array}{l}\text { Livestock produc- } \\
\text { tion and fishing }\end{array}$ & DIS & KEY & KEY & KEY & Automotive vehicles & KEY & KEY & KEY & TOT \\
\hline Mining & $\mathrm{KEY}$ & $\mathrm{KEY}$ & KEY & TOT & $\begin{array}{l}\text { Parts and acces- } \\
\text { sories for vehicles }\end{array}$ & TOT & - & - & TOT \\
\hline Food products & KEY & KEY & KEY & KEY & $\begin{array}{l}\text { Other transport } \\
\text { equipment }\end{array}$ & TOT & - & TOT & - \\
\hline Beverage products & - & TOT & TOT & TOT & $\begin{array}{l}\text { Furniture, wood } \\
\text { products and sun- } \\
\text { dries }\end{array}$ & - & - & - & - \\
\hline Tobacco products & TOT & - & - & TOT & $\begin{array}{l}\text { Electricity, gas, wa- } \\
\text { ter, and urban sani- } \\
\text { tation }\end{array}$ & - & - & - & - \\
\hline Textile products & DIS & KEY & KEY & TOT & Construction & TOT & KEY & KEY & - \\
\hline $\begin{array}{l}\text { Leather goods and } \\
\text { footwear }\end{array}$ & KEY & KEY & KEY & TOT & Trade & DIS & DIS & DIS & - \\
\hline $\begin{array}{l}\text { Clothing and acces- } \\
\text { sories }\end{array}$ & KEY & KEY & $\mathrm{KEY}$ & TOT & $\begin{array}{l}\text { Transport, storage } \\
\text { and mailing }\end{array}$ & $\mathrm{KEY}$ & $\mathrm{KEY}$ & KEY & $\mathrm{KEY}$ \\
\hline Cellulose and paper & DIS & DIS & - & TOT & $\begin{array}{l}\text { Information ser- } \\
\text { vices }\end{array}$ & - & - & - & - \\
\hline $\begin{array}{l}\text { Petroleum deriva- } \\
\text { tives and ethanol }\end{array}$ & $\mathrm{KEY}$ & KEY & KEY & DIS & $\begin{array}{l}\text { Finance and insur- } \\
\text { ance }\end{array}$ & - & - & - & - \\
\hline $\begin{array}{l}\text { Pharmaceuticals, } \\
\text { perfumery, hygiene } \\
\text { and cleaning }\end{array}$ & KEY & KEY & KEY & TOT & $\begin{array}{l}\text { Real state and } \\
\text { rental }\end{array}$ & - & - & - & - \\
\hline Rubber and plastic & - & - & - & - & $\begin{array}{l}\text { Accommodation } \\
\text { and food services }\end{array}$ & - & - & - & - \\
\hline Chemical products & DIS & DIS & DIS & - & Business services & - & - & DIS & - \\
\hline $\begin{array}{l}\text { Non-metallic miner- } \\
\text { als products }\end{array}$ & $\mathrm{KEY}$ & KEY & KEY & KEY & $\begin{array}{l}\text { Education and } \\
\text { health markets }\end{array}$ & - & - & - & - \\
\hline Metallurgy & KEY & KEY & KEY & KEY & $\begin{array}{l}\text { Public administra- } \\
\text { tion }\end{array}$ & - & - & - & - \\
\hline $\begin{array}{l}\text { Metallic products } \\
\text { (except machinery } \\
\text { and equipment) }\end{array}$ & $\mathrm{KEY}$ & KEY & KEY & KEY & Other services & - & - & - & TOT \\
\hline $\begin{array}{l}\text { Machinery and } \\
\text { equipment }\end{array}$ & TOT & TOT & - & - & & & & & \\
\hline
\end{tabular}

Source: The authors. 
relevant only in terms of their total impacts, meaning that, while their purchases remained carbon-intensive, their emissions were comparatively less affected by a given level of demand of other sectors. The opposite happened for "Petroleum derivatives and ethanol”, which, again, might be connected with substitution between fuel types.

Three key sectors displayed total or distributive impacts significantly above average during the entire period. Plotting these impacts allows for the visualization of how much these three sectors stand out (Figure 2). "Petroleum derivatives and ethanol" (the energy sector) exhibited the highest distributive impacts during the whole period, a consequence of the fact that it constitutes the sole supply of fuels for all other sectors. Figure 2 shows how its distributive impacts sharply decreased between 2005 and 2008; a further and less pronounced reduction took place between 2008 and 2013; lastly, a reversal occurred in the final interval. This result can be explained not only by shifts in the demand for fuel from other sectors, but also by the reduction of carbon content in the production of the sector by means of the adoption of less carbon-intensive technologies, which would also elucidate the reduction of its total impacts (which happened during all intervals).

Figure 2. Total and distributive impacts

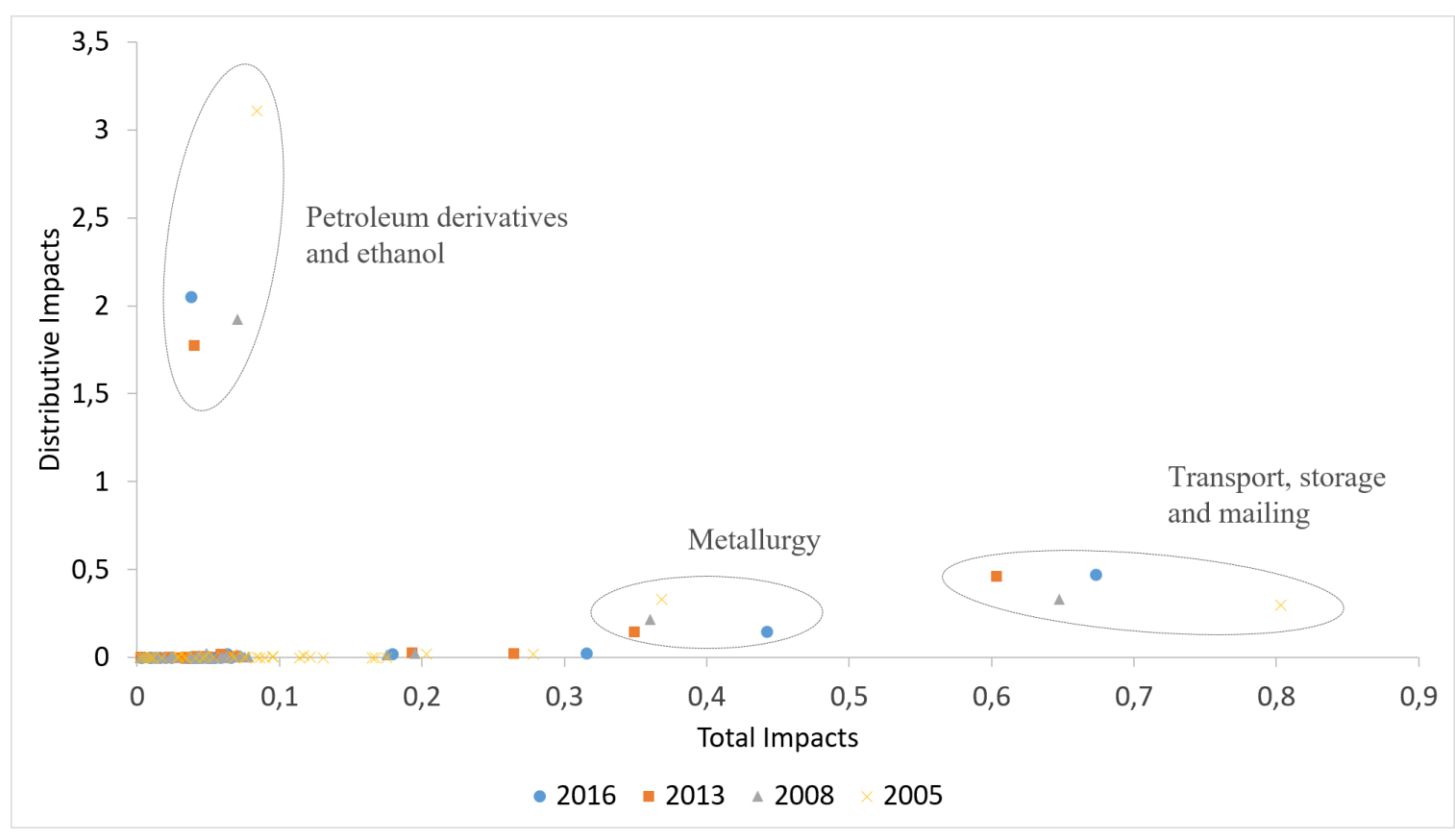

Source: The authors.

"Transport, storage and mailing" presented the highest total impacts, which is attributed to its great demand for fuels. A similar dynamic was here in effect: total impact reductions which diminish over time and finally a trend reversal. Such results could be justified in different ways, including the hypotheses of efficiency gains (fleet renewal, transition to other transportation modals, and use of biofuels or hybrid ve- 
hicles) or of higher demand of other sectors for fuel (once impacts must be regarded in relation to other sectors). The distributive impacts of the transport sector also stood out during the whole period, especially since they grew by more than $50 \%$ (from 0.30 to 0.47 ). Overall, it is fair to say that this sector tends to develop tighter productive linkages with its demanding sectors.

"Metallurgy" exhibited high total impacts due to the also high energy content of its productive processes. Such impacts decreased from 0.37 to 0.27 between 2005 and 2013, followed by an increase to 0.30 in 2016. This tendency means that the energy content of metallurgical productive processes might have been diminishing at a faster pace than those of the aggregate of the remaining sectors, notwithstanding the 2016 increase due to the influence of external macroeconomic factors. Its distributive impacts are also relevant, although declining over time (except for a small increase in 2016), which suggests that its emissions are gradually becoming less connected with the demand of other sectors for its products.

\subsection{Emissions embedded in exports}

Emissions embedded in the State's international exports are shown in Table 4. "Metallurgy", "Transport, storage and mailing”, "Mining”, "Agriculture, forestry and logging", and "Petroleum derivatives and ethanol" had the highest amount of emissions embedded in exports. One of the most important exporting sectors of the State in monetary terms, "Metallurgy" exports were responsible for the emission of 7.3 million Tons of carbon in 2005, 7.1 million Tons in 2008, 5.1 million Tons in 2013, and 6.5 million Tons in 2016. Such a declining trend (with the exception of the increase between 2013 and 2016, which is due to a particularly large increase in the total nominal value of the sector's exports) is mainly caused by a strong reduction of metallurgy's total emission requirements.

The exports of "Transport, storage and mailing" led to the emission of 2.0, 1.3, 1.6, and 1.9 million Tons of carbon in 2005, 2008, 2013, and 2016 respectively. Such results can be explained, on the one hand, by the trend of reduction in total requirements of the sector, as presented in Table 4. On the other hand, there was a decline in monetary export values between 2005 and 2008, followed by a sharp recovery between 2008 and 2013, and by yet another rise between 2013 and 2016, which account for the U-shaped behavior of emissions accruing from exports of the sector.

Emissions embedded in the exports of "Mining" increased from circa 1.5 million Tons in 2005 to 2.0 million Tons in 2008 and 2013, before dropping to 1.4 million Tons in 2016. While total emission requirements reduced significantly in the period (see Table 4) - except for a marginal increase in 2016 - exports in monetary units skyrocketed between 2005 and 2013, and then fell between 2013 and 2016. As a result, overall emissions from mining exports slightly decreased over the whole period. A similar behavior was observed for "Agriculture, forestry and logging": even though nominal export values increased more than three-fold, its emissions only grew by $43 \%$ 
Table 4. Emissions embedded in exports (Gg)

\begin{tabular}{|c|c|c|c|c|c|c|c|c|c|}
\hline Sector & 2005 & 2008 & 2013 & 2016 & Sector & 2005 & 2008 & 2013 & 2016 \\
\hline $\begin{array}{l}\text { Agriculture, } \\
\text { forestry and logging }\end{array}$ & 752.1 & 675.7 & 781.4 & $1,072.3$ & $\begin{array}{l}\text { Electrical materials, } \\
\text { appliances and } \\
\text { equipment }\end{array}$ & 65.2 & 54.2 & 26.3 & 26.5 \\
\hline $\begin{array}{l}\text { Livestock produc- } \\
\text { tion and fishing }\end{array}$ & 2.2 & 34.5 & 27.3 & 41.1 & Automotive vehicles & 220.4 & 253.9 & 142.8 & 96.4 \\
\hline Mining & $1,472.7$ & $1,975.3$ & $1,977.7$ & $1,440.1$ & $\begin{array}{l}\text { Parts and acces- } \\
\text { sories for vehicles }\end{array}$ & 88.1 & 77.4 & 82.2 & 50.1 \\
\hline Food products & 230.1 & 291.8 & 387.9 & 427.3 & $\begin{array}{l}\text { Other transport } \\
\text { equipment }\end{array}$ & 0.3 & 5.0 & 6.6 & 2.6 \\
\hline Beverage products & 0.1 & 22.9 & 0.6 & 0.8 & $\begin{array}{l}\text { Furniture, wood } \\
\text { products and sun- } \\
\text { dries }\end{array}$ & 8.0 & 11.5 & 12.6 & 10.7 \\
\hline Tobacco products & 0.1 & 0.0 & 0.1 & 0.2 & $\begin{array}{l}\text { Electricity, gas, wa- } \\
\text { ter, and urban sani- } \\
\text { tation }\end{array}$ & 0.0 & 0.0 & 0.0 & 0.0 \\
\hline Textile products & 28.4 & 28.5 & 8.5 & 9.9 & Construction & 0.0 & 0.0 & 0.0 & 0.0 \\
\hline $\begin{array}{l}\text { Leather goods and } \\
\text { footwear }\end{array}$ & 9.9 & 8.0 & 21.0 & 23.9 & Trade & 130.3 & 93.5 & 133.4 & 140.8 \\
\hline $\begin{array}{l}\text { Clothing and acces- } \\
\text { sories }\end{array}$ & 1.3 & 11.9 & 1.0 & 0.7 & $\begin{array}{l}\text { Transport, storage } \\
\text { and mailing }\end{array}$ & $2,011.2$ & $1,340.4$ & $1,574.8$ & $1,947.5$ \\
\hline Cellulose and paper & 94.3 & 103.0 & 86.3 & 90.5 & $\begin{array}{l}\text { Information ser- } \\
\text { vices }\end{array}$ & 0.0 & -0.1 & 0.0 & 0.1 \\
\hline $\begin{array}{l}\text { Petroleum deriva- } \\
\text { tives and ethanol }\end{array}$ & 52.2 & 354.9 & 491.2 & 467.2 & $\begin{array}{l}\text { Finance and insur- } \\
\text { ance }\end{array}$ & 0.0 & 0.0 & 0.0 & 0.0 \\
\hline $\begin{array}{l}\text { Pharmaceuticals, } \\
\text { perfumery, hygiene } \\
\text { and cleaning }\end{array}$ & 1.3 & 10.5 & 44.4 & 31.4 & $\begin{array}{l}\text { Real state and } \\
\text { rental }\end{array}$ & 0.0 & 0.0 & 0.0 & 0.0 \\
\hline Rubber and plastic & 7.2 & 9.8 & 7.3 & 4.9 & $\begin{array}{l}\text { Accommodation } \\
\text { and food services }\end{array}$ & 0.0 & 0.2 & 0.1 & 17.6 \\
\hline Chemical products & 118.7 & 141.6 & 75.1 & 92.6 & Business services & 0.0 & 0.1 & 0.1 & 0.1 \\
\hline $\begin{array}{l}\text { Non-metallic miner- } \\
\text { als products }\end{array}$ & 165.5 & 293.3 & 194.8 & 214.3 & $\begin{array}{l}\text { Education and } \\
\text { health markets }\end{array}$ & 0.0 & 0.3 & 0.0 & 0.0 \\
\hline Metallurgy & $7,307.2$ & $7,090.8$ & $5,085.2$ & $6,514.6$ & $\begin{array}{l}\text { Public administra- } \\
\text { tion }\end{array}$ & 0.0 & 0.3 & 0.8 & 0.4 \\
\hline $\begin{array}{l}\text { Metallic products } \\
\text { (except machinery } \\
\text { and equipment) }\end{array}$ & 148.1 & 94.0 & 89.7 & 118.7 & Other services & 0.0 & 1.4 & 0.1 & 0.4 \\
\hline $\begin{array}{l}\text { Machinery and } \\
\text { equipment }\end{array}$ & 92.6 & 35.9 & 22.1 & 18.1 & & & & & \\
\hline
\end{tabular}

Source: The authors. 
(from 0.75 million Tons in 2005 to 1.1 in 2016) due to the effect of diminishing total emission requirements.

Finally, emissions embedded in the exports of "Petroleum derivatives and ethanol" grew approximately nine times over, while the total emission requirements of the sector had a slight decrease. The underlying driver, in this case, was an incredible rise of almost 2,000\% in its nominal export values.

\section{Conclusions}

Using a hybrid input-output model, it was possible to assess the evolution of the productive structure of the State in terms of emissions from fuel combustion in the observed period. The total emission requirements of the 35 sectors of the economy of Minas Gerais were determined, as well as key sectors and emissions embedded in sectoral exports.

According to our results, "Petroleum derivatives and ethanol", "Transport, storage and mailing", "Metallurgy", "Metallic products, except machinery and equipment", and "Non-metallic minerals products" remained as the most relevant sectors in terms of carbon emissions in Minas Gerais between 2005 and 2016. Moreover, we identified gains in terms of emissions reductions per unit of final demand between 2005 and 2013, which is illustrated by diminishing total emission requirements and total and distributive impacts over time. A trend reversal could be observed between 2013 and 2016. "Mining" and "Agriculture, forestry and logging" replaced "Metallic products, except machinery and equipment" and "Non-metallic minerals products" in the list of the five more relevant sectors in terms of emissions embedded in exports, given the weight of their monetary export sales.

Regarding the economy of the State as a whole, results showed that, between 2005 and 2016, sectoral average and aggregate emission requirements dropped by approximately 20\%. Although this observation suggests that many economic activities might have adopted more efficient production technologies in terms of emissions, especially "Mining", "Transport, storage and mailing", and "Metallurgy", in which growing volumes of production did not lead to proportional emission increases, the trend reversal between 2013 and 2016 points toward the possibility that such gains were actually caused by specific economic circumstances (e.g. drastic changes in commodity prices). Moreover, the decreasing returns to the observed gains might indicate that, notwithstanding macroeconomic fluctuations, further advancements will depend on additional, more profound changes in the economy of the State.

The results above are useful as tools for formulation, analysis, and revision of mitigation policies for the State of Minas Gerais, shedding light on the behavior of particular sectors and the evolution of their emission profiles within the productive structure. Thus, these results can serve as instruments for improving policies aimed at the integration of economic and environmental goals. Understanding how sectors 
are interlinked and how such interlinkages influence carbon emissions within a given economy over time constitute a fruitful opportunity to accomplish more effective assessments and propositions regarding the challenges posed by climate change.

\section{References}

Alcántara, V. and Padilla, E. (2003). "Key" sectors in final energy consumption: an input-output application to the Spanish case. Energy Policy, 31(15):1673-1678.

Alvim, C. (2000). Módulo de emissões por setor e aplicação para caso exemplo (setor agropecuário) e extensão para outros setores. Economia e Energia, Brasília.

Carvalho, T. S. and Perobelli, F. S. (2009). Avaliação da intensidade de emissões de $\mathrm{CO}_{2}$ setoriais e na estrutura de exportações: um modelo interregional de insumoproduto São Paulo/restante do Brasil. Economia Aplicada, 13(1):99-124.

Carvalho, T. S., Santiago, F. S., and Perobelli, F. S. (2013). International trade and emissions: the case of the Minas Gerais state-2005. Energy Economics, 40:383395.

CEMIG (2000). 33 Balanço Energético do Estado de Minas Gerais. CEMIG, Belo Horizonte.

CMMC (2013). Legislação brasileira sobre mudanças climáticas. Congresso Nacional, Brasília.

FEAM (2013). Estimativas de emissões e remoções de gases de efeito estufa do Estado de Minas Gerais - ano base 2010. FEAM, Belo Horizonte.

FEAM (2015). Plano de energia e mudanças climáticas de Minas Gerais. Sumário executivo. FEAM, Belo Horizonte.

FJP (2008). Tabela de recursos e usos (TRU-Regional) e matriz de insumo-produto para o Estado de Minas Gerais para o ano de 2005. FJP, Belo Horizonte.

FJP (2012). Produto interno bruto de Minas Gerais / 2010. FJP, Belo Horizonte.

FJP (2015). Tabela de recursos e usos e matriz de insumo-produto de Minas Gerais 2008. FJP, Belo Horizonte.

FJP (2018a). Anexo estatístico - PIB MG anual - 2002-2017 (retropolação). FJP, Belo Horizonte.

FJP (2018b). Tabela de recursos e usos e matriz de insumo-produto de Minas Gerais 2013. FJP, Belo Horizonte.

FJP (2020). Tabela de recursos e usos e matriz de insumo-produto de Minas Gerais 2016. FJP, Belo Horizonte. 
Gay, P. W. and Proops, J. L. (1993). Carbon dioxide production by the UK economy: An input-output assessment. Applied Energy, 44(2):113-130.

Gowdy, J. M. and Miller, J. L. (1987). Technological and demand change in energy use: an input-output analysis. Environment and Planning A, 19(10):1387-1398.

Hannon, B. (2010). The role of input-output analysis of energy and ecologic systems: In the early development of ecological economics-a personal perspective. Annals of the New York Academy of Sciences, 1185(1):30-38.

Hawdon, D. and Pearson, P. (1995). Input-output simulations of energy, environment, economy interactions in the UK. Energy Economics, 17(1):73-86.

Hetherington, R. (1996). An input-output analysis of carbon dioxide emissions for the UK. Energy Conversion and Management, 37(6-8):979-984.

Hilgemberg, E. M. (2004). Quantificação e efeitos econômicos do controle de emissões de $\mathrm{CO}_{2}$ decorrentes do uso de gás natural, álcool e derivados de petróleo no Brasil: Um modelo interregional de insumo-produto. PhD thesis, Universidade de São Paulo.

Hilgemberg, E. M. and Guilhoto, J. J. (2006). Uso de combustíveis e emissões de $\mathrm{CO}_{2}$ no Brasil: um modelo inter-regional de insumo-produto. Nova Economia, 16(1):4999.

Labandeira, X. and Labeaga, J. M. (2002). Estimation and control of Spanish energyrelated $\mathrm{CO}_{2}$ emissions: an input-output approach. Energy Policy, 30(7):597-611.

Lenzen, M. (1998). Primary energy and greenhouse gases embodied in Australian final consumption: an input-output analysis. Energy Policy, 26(6):495-506.

Leontief, W. (1986). Input-output economics. Oxford University Press, Oxford, 2 edition.

Machado, G. V. (2002). Meio ambiente e comércio exterior: impactos da especialização comercial brasileira sobre o uso de energia e as emissões de carbono do país. $\mathrm{PhD}$ thesis, Universidade Federal do Rio de Janeiro.

Miller, R. E. and Blair, P. D. (2009). Input-output analysis: foundations and extensions. Cambridge University Press, New Jersey, 2 edition.

MINAS GERAIS (2012). Lei no 20.024, de 09 de janeiro de 2012. Institui o Plano Plurianual de Ação Governamental para o quadriênio 2012-2015 - PPAG 2012-2015. Assembléia Legislativa de Minas Gerais, Belo Horizonte.

Mongelli, I., Tassielli, G., and Notarnicola, B. (2006). Global warming agreements, international trade and energy/carbon embodiments: an input-output approach to the Italian case. Energy Policy, 34(1):88-100.

Perobelli, F. S., Faria, W. R., and Vale, V. d. A. (2015). The increase in Brazilian household income and its impact on $\mathrm{CO}_{2}$ emissions: Evidence for 2003 and 2009 from input-output tables. Energy Economics, 52:228-239. 
Perobelli, F. S., Mattos, R. S. d., and Faria, W. R. (2007). Interações energéticas entre o Estado de Minas Gerais e o restante do Brasil: uma análise inter-regional de insumo-produto. Economia Aplicada, 11(1):113-130.

Proops, J. L., Faber, M., and Wagenhals, G. (1993). Reducing $\mathrm{CO}_{2}$ Emissions: A Comparative Input-output-study for Germany and the UK. Springer Science \& Business Media.

Rasmussen, P. (1956). Studies in international relations. North Holland, Amsterdan.

Rockström, J., Steffen, W., Noone, K., Persson, Å., Chapin, F. S., Lambin, E. F., Lenton, T. M., Scheffer, M., Folke, C., Schellnhuber, H. J., et al. (2009). A safe operating space for humanity. Nature, 461(7263):472-475.

Steffen, W., Crutzen, P. J., and McNeill, J. R. (2007). The Anthropocene: are humans now overwhelming the great forces of nature. AMBIO: A Journal of the Human Environment, 36(8):614-621.

Tarancón, M. A. M. and González, P. d. R. (2007). A combined input-output and sensitivity analysis approach to analyse sector linkages and $\mathrm{CO}_{2}$ emissions. Energy Economics, 29(3):578-597.

Vale, V. A., Perobelli, F. S., and Chimeli, A. B. (2018). International trade, pollution, and economic structure: evidence on $\mathrm{CO}_{2}$ emissions for the North and the South. Economic Systems Research, 30(1):1-17.

(G) Es Este artigo está licenciado com uma CC BY 4.0 license. 